\title{
Development of Analytical Procedure for the Quantification of "Fatsiflogin"
}

\author{
M. Getia ${ }^{1}$, V. Mshvildadze ${ }^{2}$, A. Pichette ${ }^{2}$, G. Dekanosidze ${ }^{1}$, Z. Kemoklidze ${ }^{1}$ \\ ${ }^{I}$ Tbilisi State Medical University's IovelKutateladze Institute of pharmacochemistry, \\ laboratory of triterpene compounds, 36 P. Sarajishvili, 0159, Tbilisi, Georgia \\ ${ }^{2}$ Laboratoire LASEVE, Université du Québec à Chicoutimi, 555 Boul. de l'Université, \\ Département des Sciences Fondamentales, Chicoutimi, Québec, Canada
}

\begin{abstract}
Fatsiflogin" is an original, nonsteroidal para-medical preparation from the leaves of Fatsia japonica with anti-rheumatic, anti-inflammatory and analgesic activities. Fatsioside D (tetraosid of hederagenin) as one of the major compound of "Fatsiflogin", was selected as a chemical markerfor the quantitative validation. The objective of this study is to develop a simple and reliable HPLC method for the determination of Fatsiosid D for quality control studies of "Fatsiflogin". FatsiosideD was purified by preparative HPLC and the structure of the compound was determined by NMR. HPLC separation was performed on an intertsil prep-ODS C18 column, with a solvent system water-acetonitrile. The UV detection is performed at $205 \mathrm{~nm}$. The proposed HPLC method is linear in the range studied $\left(r^{2}>0.999\right)$ for all the analytes. The method is precise with intra- and inter-day variations of less than $3.34 \%$. The mean recoveries of the analytes range from 99.68 to $100.29 \%$. The method is successfully applied to the quantification of Fatsioside D. The results indicated that developed HPLC method could be used for the quality control of "Fatsiflogin".
\end{abstract}

Keywords -HPLC-DAD, quantitative validation, triterpene saponine, "Fatsiflogin", Fatsioside D, tsiajaponica, Araliaceae.

\section{INTRODUCTION}

Fatsia japonica (Thunb.) Decne et Planch. (Araliaceae) is an evergreen plant growing in the regions around Black Sea [1,2]. By Institute of Pharmacochemistry (TSMU) from the ethanolic extract of the leaves of Fatsia japonica was obtained purified fraction of triterpene glycosides ("Fatsiflogin") which possesses antirheumatic, anti-inflammatory and analgesic activities and is an original, nonsteroidal para-medical preparation [3, 4, 5, 6 ].Five triterpene glycosides (Fatsiosides) were identified in "Fatsiflogin".Fatsioside D (tetraosid of hederagenin-bidesmoside) as one of the major compound of "Fatsiflogin", was selected as a chemical marker $[8,9]$ for the quantitative validation of "Fatsiflogin".The aim of this study was the development of analytical procedures for the quantitative validation of "Fatsiflogin".

\subsection{Samples}

\section{MATERIALS AND METHODS}

The structure of Fatsioside D was confirmed by ${ }^{1} \mathrm{H}$ NMR and ${ }^{13} \mathrm{CNMR}$ spectra with comparison the reference data [10].

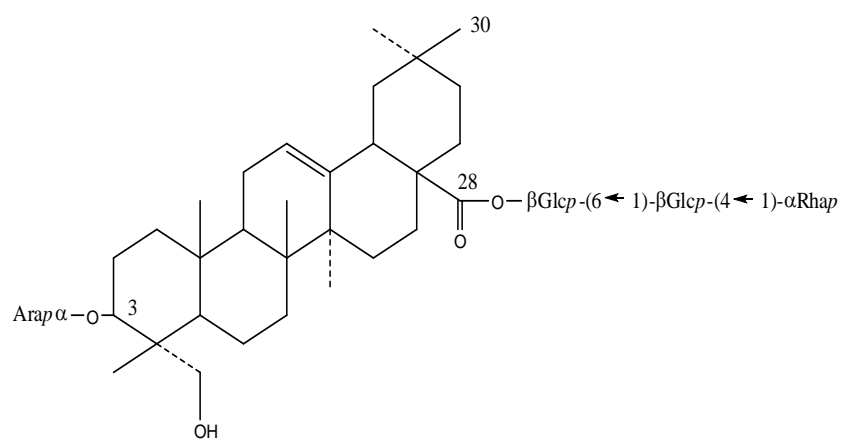

Figure 1:Fatsioside D

The purity of Fatsioside D was evaluated by analytical HPLC. The samples of "Fatsiflogin"(five batches) were protected from light and humidity until required for chemical analysis. The samples were ground to a fine powder before analysis. 


\subsection{Equipment and reagents}

HPLC grade acetonitrile and other solvents of analytical grade were purchased from VWR. Ultrapure water for HPLC analysis was obtained from a Millipor Classic purification system. Fatsioside D has been isolated from "Fatsiflogin" by previously described method[7] and the purity determined by HPLC was 99,0\%.

NMR: Structure elucidation was carried out using ${ }^{1} \mathrm{H}$ NMR (Bruker Avance $400 \mathrm{MHz}$ ), ${ }^{13} \mathrm{C}$ (Bruker Avance $100 \mathrm{MHz}$ ).The HPLC system consisted of an Agilent Technologies Model 1100 liquid chromatography, equipped with a vacuum degasser, a quaternary pump, an auto-sampler and a photodiode array detector (DAD) and MS. The system was piloted by Chemstation computer software. The chromatographic separation was achieved using an intertsil prep-ODS column C18 (6.0 x $250 \mathrm{~mm}$; $10 \mathrm{um})$. Mobile phase composed water and acetonitrile $(70 \rightarrow 30, \mathrm{v} / \mathrm{v})$. The mobile phase flow rate was $1 \mathrm{ml} / \mathrm{min}$. The injection volume was $10 \mu \mathrm{l}$. All separations were performed at room temperature. The UV spectra were recorded in the detection range of 200$400 \mathrm{~nm}$ for all peaks. Quantification was carried out at a single wavelength of $205 \mathrm{~nm}$.

Preparation of standard solution: Standard stock solution of Fatsioside D was prepared in methanol to give a final concentration of $1.0 \mathrm{mg} / \mathrm{mL}$. A series of working solutions of Fatsioside $\mathrm{D}(\mathrm{n}=5)$ was prepared in order to obtain various concentration levels $(0.0019-1.0 \mathrm{mg} / \mathrm{mL})$. The appropriate volume of stock solution of Fatsioside $\mathrm{D}$ was introduced in a $10.0 \mathrm{~mL}$ volumetric flask and the volume was adjusted to $10.0 \mathrm{~mL}$ with mobile phase. All prepared standard solutions were filtered through $0.45 \mu \mathrm{m}$ membrane filter (Millipore, ref HVPL04700) before HPLC analysis.

Preparation of sample solution: $20.0 \mathrm{mg}$ of "Fatsiflogin" was introduced in a $100 \mathrm{~mL}$ volumetric flask and solubilized in methanol and the volume was adjusted to $100.0 \mathrm{~mL}$ with methanol. Then $2 \mathrm{ml}$ of each solution were filtered through a syringe filter ( $0.45 \mathrm{~mm}$ Millipore) into a HPLC vial.

\subsection{Method Validation}

HPLC separation conditions were optimized in order to achieve satisfactory resolution [11]. The optimum separation of "Fatsiflogin" was obtained on the reversed phase prep-ODS column C18 (6.0 x $250 \mathrm{~mm}$; $10 \mu \mathrm{m})$.To provide an optimal resolution, the effect of mobile phase was examined. A satisfactory separation was detected with a mobile phase consisting of acetonitrile-water in a ratio of 30/70, v/v. The solution of Fatsioside D was prepared in methanol. The retention time of Fatsioside D was observed at 13.8 min. Measurement at $205 \mathrm{~nm}$ displayed sufficient sensitivity and a satisfactory chromatographic baseline. As a result, under the optimized conditions, a baseline separation was achieved within 25 min, with symmetrical, sharp and well-resolved peaks for Fatsioside D. The chromatogram showing the complete baseline separation of Fatsiosid $\mathrm{D}$ in "Fatsiflogin" is presented in Figure 2.

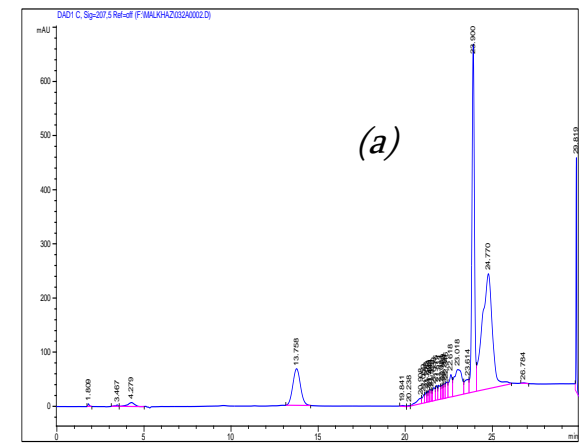

Figure 2: HPLC profile of a)Fatsioside D, b) Methanol and c) "Fatsiflogin".

This method was validated according to the ICH guidelines on the validation of analytical methods

[12].No interference and great resolution are observed of Fatsioside D and other compounds in

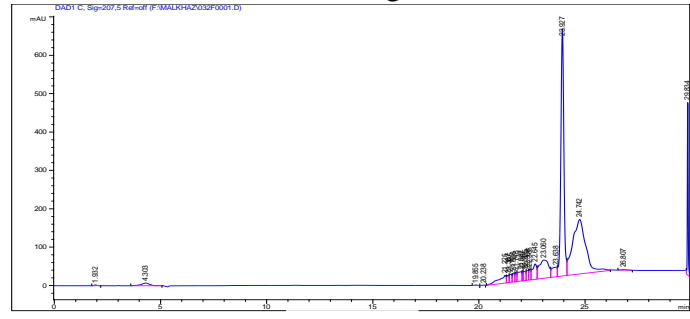

(b)

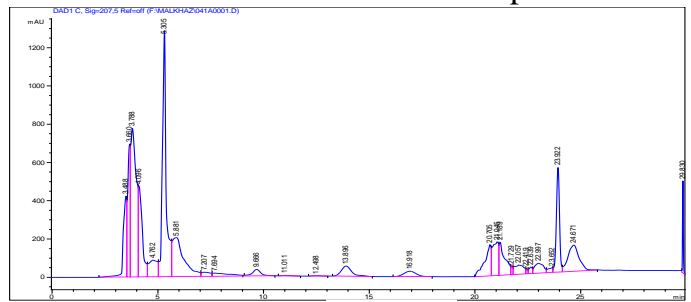

(c) 
by the comparison of retention time. Furthermore, the purities of the investigated peaks were all confirmed by DAD purity studies.

\section{RESULTS AND DISCUSSION}

For the quantitative control of Fatsioside D we have developed and validated an HPLC method for the assay of "Fatsiflogin".Linearity data are shown in Table 1 for the "Fatsiflogin". The calibration curves were linear within the concentration range. All correlation coefficients were greater than 0,999 .

\begin{tabular}{|c|c|c|c|}
\hline & & $\begin{array}{c}\text { Fatsioside D } \\
\text { Standard }\end{array}$ & $\begin{array}{l}\text { Fatsioside D } \\
\text { "Fatsiflogin" }\end{array}$ \\
\hline \multirow[b]{2}{*}{ Linearity } & Range $\mathrm{mg} / \mathrm{ml}$ & $0,007-1,0$ & $0,06-1,0$ \\
\hline & $\begin{array}{l}\text { Calibration } \\
\text { curves and } \mathbf{r}^{2}\end{array}$ & $\begin{array}{c}\mathrm{y}=2230 \mathrm{X}-2.148 \\
\mathrm{R}^{2}=0.999\end{array}$ & $\begin{array}{c}y=2052 X-1.25 \\
R^{2}=0.999\end{array}$ \\
\hline \multicolumn{2}{|l|}{ Accuracy } & & $99,98 \pm 0,28 \%$ \\
\hline \multirow{4}{*}{ Precision } & \multirow{3}{*}{$\begin{array}{c}\text { Intermediate } \\
\text { precision (Inter- } \\
\text { day, } 3 \text { days) } \\
\% \text { RSD }\end{array}$} & First day & 1.05 \\
\hline & & Second day & 2.3 \\
\hline & & Third day & 2.5 \\
\hline & $\begin{array}{c}\text { Intermediate } \\
\text { precision (Intra- } \\
\text { day) \% RSD } \\
(\mathbf{n}=18)\end{array}$ & & 3.36 \\
\hline
\end{tabular}

Table 1. Calibration parameters, accuracy, precision of Fatsiozid D in "Fatsiflogin"

The results of intra- and inter-day precision are presented in Table $\mathbf{1}$ for the "Fatsiflogin". The interday $\%$ RSD was less than $2.5 \%$ and the intra-day \% RSD was less than $3.36 \%$ showing a good precision of the method. Recoveries determined for each component were between 99.68 and $100.29 \%$ for "Fatsiflogin" and RSDs were less than $1.4 \%$ indicating a good accuracy. The limit of detection was $0.78 \mu \mathrm{g} / \mathrm{mL}$. The limit of quantification was $3.8 \mu \mathrm{g} / \mathrm{mL}$ for Fatsioside D.The validated HPLC method is successfully applied for the quantitative control of "Fatsiflogin". Fatsioside D is a characteristic compound of "Fatsiflogin". Its quantification is realized by external calibration.

\begin{tabular}{|c|c|}
\hline Batch number & $\begin{array}{c}\text { Content of Fatsioside D } \\
(\%)\end{array}$ \\
\hline 01031 & 5.06 \\
\hline 01041 & 4.99 \\
\hline 01042 & 5.27 \\
\hline 01043 & 5.47 \\
\hline 01044 & 5.12 \\
\hline
\end{tabular}

Table 2. Quantification of batches of "Fatsiflogin"

The quantitative data of the analysis of the five batches of the "Fatsiflogin" are summarized in Tables 2. The concentrations of Fatsioside D are homogeneous between the different samples. The content of Fatsioside $\mathrm{D}$ in "Fatsiflogin" is ranges from $4.99 \%$ to $5.47 \%$.

Validation and assay: The linearity of the HPLC method was performed for Fatsioside D. Five different concentrations were prepared and analysed in triplicate for each concentration. The concentration range was 0.0019 to $1.0 \mathrm{mg} / \mathrm{mL}$ for Fatsioside D. Calibration curves were constructed by plotted peak areas against concentrations. The linearity was assessed by calculating the slope, y-intercept and coefficient of correlation $\left(r^{2}\right)$ using least squares regression. The limits of detection and quantification were considered to be the concentration that produced signal-to-noise ratios of 3:1 and 10:1 respectively. The precision of the method was evaluated with respect to both intra- and inter-day precision. Intra-day precision was calculated from the analyses of six sample solutions prepared independently on one day. Inter-day precision was evaluated by repeating the same procedure on 2 other days, The standard deviation and the RSD (relative standard deviation) values were calculated for each day.The accuracy of the method was evaluated using the recovery test. This involved the spiking of known quantities of Fatsioside D standard solutions into the real samples. The standard solutions were prepared at three 
concentration levels (80,100 and 150\%). At each level, samples were analysed in triplicate according to the previously described chromatographic conditions.

\section{CONCLUSIONS}

A new, simple, sensitive and reproducible HPLC method has been developed and validated for the simultaneous quantification of triterpene saponines in "Fatsiflogin". Precision, sensitivity and linearity are satisfactory in the range studied. The proposed HPLC method is suitable for quality control of "Fatsiflogin" and could be proposed for a new "Fatsiflogin" monograph for the National Pharmacopoeia.

Acknowledgment: This work was supported (NMR study) byDr. Serge Lavoie (LASEVE, UQAC).

\section{REFERENCES}

[1] DendrofloraKavkaza. Native and cultivated trees and Shrubs. 1986. Tbilisi, "Metsniereba", Vol. 6. p. 74.

[2] KachalovA. A., Trees and Shrubs. (1970), Izd. Akad. Nauk SSSR, Lesnaya Prom-st, Moscow. 287 pages.

[3] Shalamberidze L.P., Tsitlanadze V.G., Kemertelidze E.P., kartvelishvili E. U. (1998) New plant preparation - Fatsiflogin in the theraphy of Rheumatoid Arthrits. Russian Rheumatology. 1. p. 43-46

[4] Kemertelidze E.P., Kemoklidze Z.S., Dekanosidze G.E., Berezniyakova A. I. Triterpene glycosides from Fatsia japonica Introduced in Georgia and their pharmacological activities. Chemical Pharmaceutical Journal, Moscow, 2001, vol. 35, \#8, p. 24-27

[5] Kemoklidze Z.S., Dekanosidze G.E., Kemertelidze E.P., Berezniyakova A. I., Volkovoyi V.A., Lokteva M.E. Method of reception of a medical preparation with anti-inflammatory activity, Certificate of author USSR №1541820 Published 08.10.1989.

[6] Monograph of "Fatsiflogin", Article of Pharmacopoeia No. 714-1110. Georgia, 2010

[7] Kemoklidze Z.S., Dekanosidze G.E., Jikia O.D., Vugalter M.M., Kemertelidze E.P. Triterpene Saponins From the leaves of Fatsia japonica. Chemistry of Natural Compounds, 1982, 6, Pages 788-789;

[8] KemoklidzeZ.S., DekanosidzeG.E., DzhikiyaO.D., VugalterM.M., Kemertelidze E.P. Triterpene glycosides of the leaves of Fatsia japonica. Structures of Fatsiosides D, E and F. Chemistry of Natural Compounds, 1983, 4, Pages 252-253;

[9] Kemoklidze Z.S., Dekanosidze G.E., Jikia O.D., Vugalter M.M., Kemertelidze E.P. Triterpene Saponins From Fatsia japonica Growing in Georgia. (1987). Bulletin of the academy sciences of the Georgian SSR. 125,3 , p. $569-572$

[10] Grishkovets V. I., Sobolev E. A., Shashkov A. S., Chirva V. Ya. Triterpenoid glicosydes of Fatsia japonica. II. Isolation and structure of glycosides from the leaves. Chemistry of Natural Compounds, 2000.Vol. 36, No. 5

[11] Lloyd R. Snyder, Joseph Jack Kirkland, Joseph L. Glajch. Practical Hplc Method Development. 1997. Second edition. New York. 765 pages

[12] Validation of analytical procedures: Text and methodology - International Conference on Harmonisation. ICH-Q2 (R1) (2005) Geneva. 